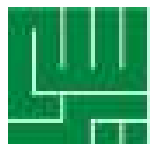

\title{
Pengaruh Pemberian Air Jeruk Nipis (Citrus aurantifolia) Terhadap Konsentrasi dan Motilitas Spermatozoa Mencit (Mus musculus) Setelah Terpapar Asap Rokok
}

\section{The Effects of Key Lime (Citrus aurantifolia) on Concentration and Motility of Mice (Mus musculus) Spermatozoa After Exposure of Cigarette Smoke}

Nisa Ihsani, Nelis Hernahadini, Linda Pertiwi. Muhammad Kahfi N.F., and Sara Noer Fadhillal'?

Department of Biotechnology. Universitas Muhammadiyah Bandung, Jawa Barat

KATA KUNCI KEYWORDS

ABSTRAK

ABSTRACT
Citrus aurantifolia, Mus musculus, rokok, spermatozoa Citrus aurantifolia, Mus musculus, cigarette, spermatozoa

Merokok telah dikenal sebagai salah satu penyebab masalah kesehatan paru-paru, jantung, gastrointestinal, dan kesuburan. Efek asap rokok terhadap kesuburan dapat dilihat dari penurunan kualitas dan kuantitas spermatozoa. Konsumsi makanan yang mengandung vitamin $C$ diketahui dapat menekan penurunan kuantitas dan kualitas spermatozoa perokok aktif. Tujuan penelitian ini adalah untuk mengetahui pengaruh pemberian jeruk nipis terhadap konsentrasi spermatozoa dan persentase motilitas spermatozoa abnormal Mus musculus. Pada penelitian ini dilakukan pemberian jeruk nipis sebagai sumber vitamin C pada mencit (Mus musculus) untuk menentukan pengaruh pemberian jeruk nipis terhadap konsentrasi dan motilitas spermatozoa mencit (Mus musculus) yang telah terpapar asap rokok. Hasil penelitian menunjukkan bahwa pemberian jeruk nipis sebanyak $1 \mathrm{~mL} / 100$ gram BB mencit dapat meningkatkan konsentrasi spermatozoa dan menurunkan persentase motilitas spermatozoa abnormal mencit setelah paparan asap rokok selama 10 menit.

Smoking has been known as a causative agent of many health problems related to lung, heart, gastrointestinal, and fertility. The effect of cigarrete smoke against fertility has been proven lowering both quality and quantity of spermatozoa. On the other hand, some studies stated that consumption of Vitamin C hinders the lowering quality and quantity of spermatozoa in 
active smokers. In this study, we applied a dose of vitamin $C$ from key lime (Citrus aurantifolia) to mice (Mus musculus) to determine its effect to concentration and motility of mice spermatozoa, which had been previously exposed with cigarette smoke. Result showed that the administration of key lime with dose of $1 \mathrm{~mL} / 100 \mathrm{~g} W W$ mice is able to increase spermatozoa concentration while decreasing the percentage of abnormal motility spermatozoa after 10 minutes exposure of cigarette smoke.

Merokok telah diketahui sebagai salah satu penyebab masalah kesehatan di dunia. Kandungan zat-zat berbahaya di dalam asap rokok berpotensi menyebabkan berbagai macam pengaruh buruk terhadap kesehatan seperti: penyakit paru-paru (Tommola et al., 2016), kesuburan (Kovac, Khanna and Lipshultz, 2015), inflamasi gastrointestinal (Berkowitz et al., 2018), dan penyakit kardiovaskuler (Papathanasiou et al., 2014). Meskipun demikian, bahaya merokok tidak menyurutkan keinginan para perokok untuk berhenti mengkonsumsi produk olahan tembakau ini. Bedasarkan data WHO, Indonesia telah menduduki peringkat ketiga sebagai negara dengan jumlah perokok terbanyak di dunia, setelah Cina dan India (Kementrian kesehatan RI, 2015) Pada tahun 2018, Riset Kesehatan (Rikesdas) telah mencatat bahwa $62,9 \%$ perokok Indonesia yang berusia di atas 15 tahun berjenis kelamin laki-laki (Kementrian kesehatan RI, 2018).

Berbagai penelitian telah membuktikan bahwa asap rokok berpengaruh terhadap kualitas dan kuantitas sperma. Ramlau-Hansen et al., (2007) membuktikan bahwa pria perokok memiliki volume semen, jumlah sperma, dan persentase motilitas sperma yang rendah dibandingkan dengan pria yang tidak merokok. Dalam penelitiannya dijelaskan bahwa laki-laki dengan frekuensi merokok lebih dari 20 rokok per hari dapat menurunkan 19\% konsentrasi sperma. Salah satu penyebab penurunan kualitas dan kuantitas sperma adalah keberadaan nikotin pada rokok. Pemberian nikotin secara oral dapat menyebabkan penurunan jumlah dan persentase motilitas sperma serta meningkatkan persentase abnormalitas sperma tikus (Oyeyipo et al., 2011).

Beberapa jenis makanan dipercaya dapat meningkatkan kuantitas dan kualitas sperma. Salah satunya yaitu makanan yang banyak mengandung vitamin C. Vijayprasad, Ghongane dan Nayak (2014) dalam penelitiannya menjelaskan bahwa jumlah dan motilitas sperma tikus jantan yang telah diberi cekamanan stress meningkat secara signifikan setelah pemberian vitamin $\mathrm{C}$ dengan dosis $10 \mathrm{mg} / \mathrm{kg} /$ hari hingga 30 $\mathrm{mg} / \mathrm{kg} /$ hari. Begitupun dengan hasil penelitian Sutanto et al., (2017) yang membuktikan bahwa pemberian vitamin $C$ dan $E$ pada tikus dapat meningkatkan konsentrasi dan motilitas sperma tikus.

Correspondence:

Nisa Ihsani, Department of Biotechnology, Universitas Muhammadiyah Bandung, Jawa Barat

Email: nisaihsani161@gmail.com 
Efek antioksidan pada vitamin C dan E diduga dapat melindungi kerusakan sperma dari oxidative stress yang dapat menurunkan kualitas dan kuantitas sperma. Jeruk nipis (Citrus aurantifolia) adalah tumbuhan yang berasal dari Asia dan tumbuh subur pada daerah beriklim tropis seperti Indonesia (Donkersley et al., 2018). Spesies yang berasal dari famili Rutaceae ini memiliki banyak kandungan senyawa yang bermanfaat bagi tubuh, diantarnya yaitu: flavonoid, limonoid, phenol, karotenoid, mineral, dan vitamin $C$.

Hal ini menyebabkan jeruk nipis memiliki kemampuan sebagai antiseptik, antiviral, antifungal, dan antioksidan (Enejoh, Ogunyemi and Bala, 2015). Banyaknya kandungan senyawa yang bermanfaat dalam jeruk nipis berpotensi untuk memperbaiki kerusakan di dalam tubuh. Salah satunya yaitu kerusakan yang menyebabkan terjadinya penurunan kualitas dan kuantitas spermatozoa yang disebabkan oleh asap rokok. Oleh karena itu, perlu dilakukan penelitian dengan menggunakan hewan uji mengenai penentuan pengaruh pemberian jeruk nipis terhadap konsentrasi dan motilitas spermatozoa pada mencit yang telah terpapar asap rokok. Tujuan penelitian ini adalah untuk mengetahui pengaruh pemberian jeruk nipis terhadap konsentrasi spermatozoa dan persentase motilitas spermatozoa abnormal Mus musculus.

\section{BAHAN DAN CARA KERJA}

\section{Bahan}

Pada penelitian ini digunakan mencit (Mus musculus) Swiss Webster jantan yang berusia 10 minggu sebagai hewan percobaan yang diperoleh dari SITH, ITB. Jeruk nipis (Citrus aurantifolia) diperoleh dari kebun kawasan Kabupaten Cibeureum, Jawa Barat. Pada penelitian ini juga digunakan rokok magnum filter, $\mathrm{NaCl}$ $0,9 \%$, dan air akuades.

\begin{abstract}
Alat
Alat-alat yang digunakan dalam penelitian ini antara lain: kotak pendedahan a2).sap rokok berukuran 30 x $21 \times 20 \mathrm{~cm}^{3}$ dengan dua ventilasi berdiameter $1 \mathrm{~cm}$, jarum sonde mencit oral, alat bedah, hemocytometer, kaca objek, mikropipet, syringe $1 \mathrm{~mL}$, timbangan, cawan petri, alat penghitung/ counter, gelas kimia, gelas ukur, pipet tetes, dan mikroskop cahaya binokuler.
\end{abstract}

\section{Cara Kerja \\ Persiapan dan Perlakuan}

Sebanyak 12 mencit jantan dibagi menjadi 4 kelompok, yakni: 1). kelompok kontrol (K0) yaitu mencit yang tidak dipaparkan asap rokok dan tidak diberi akuades ataupun jeruk nipis, 2). kelompok kontrol perlakuan gavage (KP) yaitu mencit yang dipaparkan asap rokok dan diberi air akuades, 3). kelompok perlakuan (P1) yaitu mencit yang dipaparkan asap rokok dan pemberian jeruk nipis 1 $\mathrm{mL} / 100$ gram BB, dan 4). kelompok perlakuan (P2) yaitu mencit yang dipaparkan asap rokok dan pemberian jeruk nipis $2 \mathrm{~mL} / 100$ gram BB. Pemberian dosis jeruk nipis mengacu pada metode Harahap dkk. (2011). Pada kelompok KP, P1, dan P2, mencit dipaparkan asap rokok dalam kotak pendedahan asap rokok selama 10 menit. Setelah itu, masing-masing perlakuan diberikan larutan air akuades atau jeruk nipis sesuai dosis dengan menggunakan jarum sonde oral. Proses ini dilakukan setiap hari sebanyak satu kali selama 6 hari berturut-turut. Pada 
hari ke-7, seluruh mencit dibedah untuk diambil kauda epididimisnya. Kauda epididimis dicacah kemudian ditambahkan $\mathrm{NaCl} 0,9 \%$ sebanyak $1 \mathrm{~mL}$. Larutan berisi spermatozoa yang diperoleh kemudian diencerkan dengan faktor pengenceran $50 x$.

\section{Perhitungan Konsentrasi Spermatozoa}

Sebanyak $10 \mu \mathrm{L}$ spermatozoa dimasukkan ke dalam seluruh ruang perhitungan hemocytometer menggunakan mikropipet. Setelah itu, spermatozoa dihitung menggunakan counter dengan bantuan mikroskop cahaya binokuler dengan perbesaran lensa okuler $x$ objektif sebesar 400x. Rata-rata jumlah spermatozoa yang terhitung dari seluruh ruang hemocytometer (N) dimasukkan ke dalam rumus:

Konsentrasi spermatozoa (sperma/ mL) $=\mathrm{N} \times 5 \times 10^{4} \times$ faktor pengenceran.

Perbedaan konsentrasi spermatozoa pada kelompok sampel dianalisis dengan uji statistik $\mathrm{T}$ test menggunakan software SPSS 20.

\section{Perhitungan Motilitas Spermatozoa}

Larutan berisi spermatozoa diteteskan pada kaca objek sebanyak 70 $\mu \mathrm{L}$, kemudian diamati menggunakan mikroskop cahaya binokuler dengan perbesaran lensa okuler $x$ objektif sebesar 400x. Spermatozoa dengan motilitas normal (bergerak lurus ke depan) dan abnormal (tidak bergerak/ berputar di tempat) dihitung, kemudian ditentukan persentase motilitas spermatozoa abnormal. Perbedaan persentase motilitas spermatozoa abnormal pada kelompok sampel dianalisis dengan dengan uji statistik $\mathrm{T}$ test menggunakan software SPSS 20.

\section{HASIL}

Perbedaan konsentrasi dan motilitas spermatozoa mencit dari berbagai perlakuan terdapat pada Tabel 1 dan 2.

Tabel 1. Tabel rerata konsentrasi spermatozoa mencit (juta/ mL)

\begin{tabular}{lcc}
\hline $\begin{array}{l}\text { Kelompok } \\
\text { perlakuan* }\end{array}$ & Rerata konsentrasi spermatozoa (juta/ mL) & \pm SD \\
\hline K0 & 246 & 14 \\
KP & 127 & 11 \\
P1 & 224 & 12 \\
P2 & 119 & 13 \\
\hline
\end{tabular}

${ }^{*}$ K0: mencit yang tidak dipaparkan asap rokok dan tidak diberi akuades ataupun jeruk nipis; KP: mencit yang dipaparkan asap rokok dan diberi air akuades; P1: mencit yang dipaparkan asap rokok dan pemberian jeruk nipis $1 \mathrm{~mL} / 100$ gram BB; P2: mencit yang dipaparkan asap rokok dan pemberian jeruk nipis $2 \mathrm{~mL} / 100$ gram BB 
Tabel 2. Tabel persentase motilitas spermatozoa abnormal mencit (\%)

\begin{tabular}{lcc}
\hline $\begin{array}{l}\text { Kelompok } \\
\text { perlakuan* }\end{array}$ & $\begin{array}{c}\text { Persentase motilitas spermatozoa abnormal } \\
\text { mencit }(\%)\end{array}$ & \pm SD \\
\hline K0 & 6,81 & 0,74 \\
KP & 80,16 & 2,92 \\
P1 & 61,32 & 4,03 \\
P2 & 83,25 & 4,26 \\
\hline
\end{tabular}

*K0: mencit yang tidak dipaparkan asap rokok dan tidak diberi akuades ataupun jeruk nipis; KP: mencit yang dipaparkan asap rokok dan diberi air akuades; P1: mencit yang dipaparkan asap rokok dan pemberian jeruk nipis $1 \mathrm{~mL} / 100$ gram BB; P2: mencit yang dipaparkan asap rokok dan pemberian jeruk nipis $2 \mathrm{~mL} / 100$ gram

\section{PEMBAHASAN}

Hasil penelitian pada Tabel 1 menunjukkan bahwa konsentrasi spermatozoa pada kelompok mencit yang telah dipaparkan asap rokok (KP) lebih rendah dibandingkan dengan kelompok kontrol (K0) ( $\mathrm{p}>0,05)$. Hal ini sesuai dengan hasil penelitian RamlauHansen et al. (2007) dan Oyeyipo et al. (2011) yang membuktikan bahwa asap rokok dapat menurunkan jumlah spermatozoa. Demikian pula dengan persentase motilitas spermatozoa abnormal mencit. Hasil penelitian pada Tabel 2 menunjukkan bahwa persentase motilitas spermatozoa abnormal mencit pada kelompok KP lebih tinggi dibandingkan dengan kelompok $\mathrm{KO}$ $(p>0,05)$. Rendahnya kuantitas dan kualitas spermatozoa ini dapat disebabkan oleh senyawa berbahaya yang terkandung pada asap rokok, salah satunya yaitu nikotin. Oyeyipo et al. (2011) membuktikan bahwa nikotin dengan konsentrasi 0,5 dan $10 \mathrm{mg} / \mathrm{kg}$ BB dapat menurunkan konsentrasi spermatozoa dan meningkatkan abnormalitas spermatozoa secara signifikan pada tikus. Nikotin dalam asap rokok dapat mengganggu proses respirasi seluler dalam mitokondria yang berujung pada peningkatan pembentukan reactive oxygen species (ROS), yakni superoksida anion dan hidrogen peroksida (Mohod et al., 2014). Anyanmu et al. (2018) dalam penelitiannya pun menyebutkan bahwa asap rokok dapat memicu pembentukan ROS dan menginduksi oxidative stress dengan meningkatkan pro-oksidan dan menurunkan proteksi dari antioksidan. Kerusakan oksidatif yang dapat terjadi dalam hal ini yaitu mutasi pada DNA mitokondria yang berpotensi menyebabkan pembentukan sperma abnormal serta terjadinya proses apoptosis sel yang berujung pada penurunan jumlah sperma (Nakada et al., 2006). Selain itu, membran plasma sperma yang kaya akan polysaturated fatty acids (PUFAs) merupakan salah satu target ROS dalam peroksidasi lipid. Kerusakan oksidatif pada membran plasma ini menyebabkan terjadinya kerusakan pada struktur organel, transduksi sinyal, fungsi sistem transportasi molekul, regulasi metabolit, dan pembentukan ATP yang selanjutnya dapat menyebabkan terjadinya penurunan viabilitas dan motilitas sperma (Sutanto et al., 2017).

Adanya pengaruh pemberian jeruk nipis terhadap kuantitas dan 
kualitas spermatozoa terlihat pada perbedaan angka yang diperoleh antara kelompok P1 dan KP (Tabel 1 dan 2). Konsentrasi spermatozoa pada kelompok P1 lebih tinggi dibandingkan dengan kelompok KP (Tabel 1) ( $p>0,05)$. Hasil analisis persentase motilitas spermatozoa abnormal pun menunjukkan angka yang lebih rendah pada kelompok P1 dibandingkan dengan kelompok KP (Tabel 2) ( $p>0,05)$. Meskipun hasil analisis statistika tidak menjunjukkan perbedaan yang signifikan, akan tetapi adanya perbedaan konsentrasi dan persentase motilitas spermatozoa abnormal pada kedua kelompok ini menunjukkan bahwa pemberian jeruk nipis berpengaruh terhadap kuantitas dan kualitas spermatozoa. Pemberian jeruk nipis sebanyak $1 \mathrm{~mL} / 100$ gram BB mencit dapat meningkatkan konsentrasi spermatozoa dan menurunkan persentase motilitas spermatozoa abnormal setelah mencit terkena paparan asap rokok. Efek pemberian jeruk nipis terhadap peningkatan kuantitas dan kualitas spermatozoa dapat disebabkan oleh kandungan senyawa dalam jeruk nipis. Vitamin $C$ dalam jeruk nipis yang berperan sebagai antioksidan dapat melindungi kerusakan sperma dari oxidative stress (Shabanian et al., 2017) akibat paparan asap rokok. Dalam mekanismenya, vitamin C atau asam xyloaskorbat dapat menurunkan oxidative stress yang dapat menyebabkan terjadinya peroksidase lipid. Penurunan peroksidase lipid ini selanjutnya dapat menekan penurunan motilitas dan konsentrasi sperma (Alvarez et al., 1978). Selain vitamin C, kandungan flavonoid dalam jeruk nipis juga berperan sebagai senyawa antioksidan. Moretti et al. (2012) dalam penelitiannya membuktikan bahwa flavonoid quercetin, rutin, dan naringenin dapat menurunkan peroksidase lipid yang dapat menyebabkan penurunan kualitas dan kuantitas sperma.

Berbeda dengan kelompok P1, pemberian jeruk nipis $2 \mathrm{~mL} / 100$ gram BB pada kelompok P2 menghasilkan jumlah spermatozoa yang lebih rendah dibandingkan dengan kelompok KP (Tabel 1) $(p>0,05)$ dengan perbedaan yang tidak signifikan. Persentase motilitas spermatozoa abnormal pada kelompok P2 pun lebih tinggi dibandingkan dengan kelompok KP $(p>0,05)$. Rendahnya kuantitas dan kualitas spermatozoa ini dapat disebabkan oleh tingginya konsentrasi jeruk nipis yang diberikan kepada kelompok P2. Konsentrasi jeruk nipis yang terlalu tinggi dapat menyebabkan kadar asam dalam jeruk nipis berbahaya bagi tubuh mencit. Suthutvoravut and Kamyarat (2016) menyatakan bahwa kondisi asam yang tinggi dari tumbuhan famili Citrus lainnya yaitu lemon dapat menyebabkan sperma imobile, perubahan morfologi yang bersifat ireversibel, dan kematian pada sel sperma.

\section{SIMPULAN DAN SARAN}

\section{Simpulan}

Dari penelitian ini disimpulkan bahwa pemberian jeruk nipis sebanyak $1 \mathrm{~mL} / 100$ gram BB mencit meningkatkan konsentrasi spermatozoa dan menurunkan persentase abnormalitas spermatozoa setelah paparan asap rokok selama 10 menit.

\section{Saran}

Masyarakat khususnya laki-laki perlu menghindari kebiasaan merokok karena merokok dapat menurunkan konsentrasi spermatozoa dan 
meningkatkan abnormalitas spermatozoa. Pemberian jeruk nipis dengan konsentrasi yang tepat diharapkan dapat memperbaiki penurunan kualitas dan kuantitas spermatozoa yang disebabkan oleh paparan asap rokok.

\section{Ucapan Terima Kasih}

Ucapan terima kasih diberikan kepada kampus Universitas Muhammadiyah Bandung yang telah memfasilitasi penelitian. Kami juga mengucapkan terima kasih kepada warga Bioteknologi Universitas Muhammadiyah Bandung atas bantuan dan dukungannya serta editor Jurnal Kedokteran YARSI yang telah menelaah jurnal penelitian ini.

\section{KEPUSTAKAAN}

Alvarez JG et al., 1978. 'Spontaneous peroxidation and production of hydrogen peroxide and superoxide in human spermatozoa', Journal of Andrology, 8, pp. 338-348.

Berkowitz L et al., 2018. 'Impact of cigarette smoking on the gastrointestinal tract inflammation: Opposing effects in Crohn's disease and ulcerative colitis', Frontiers in Immunology, 9(JAN), pp. 110.

Donkersley P et al., 2018. 'Biological, environmental and socioeconomic threats to citrus lime production', Journal of Plant Diseases and Protection. Springer Berlin Heidelberg, 125(4), pp. 339-356.

Enejoh OS, Ogunyemi IO and Bala MS 2015. 'Ethnomedical Importance of Citrus Aurantifolia ( Christm ) Swingle', The Pharma Innovation Journal, 4(8), pp. 1-6.

Kementrian kesehatan RI 2015. Perilaku Merokok Masyarakat Indonesia Berdasarkan Riskesdas 2007 dan 2013, Infodatin.

Kementrian kesehatan RI 2018. Hasil utama riskesdas 2018. doi: 1 Desember 2013.
Kovac JR, Khanna A and Lipshultz LI 2015. 'The effects of cigarette smoking on male fertility', Postgraduate Medicine, 127(3), pp. 338-341.

Mohod K et al., 2014. 'Circulating Lipid Peroxide and Antioxidant Status in Cigarette Smokers: An International Journal of Health Sciences and Research', International Journal of Health Sciences and Research, 4(5), pp. 59-65.

Moretti E et al., 2012. 'Effect of quercetin, rutin, naringenin and epicatechin on lipid peroxidation induced in human sperm', Reproductive Toxicology, 34, pp. 651-657.

Nakada K et al., 2006. 'Mitochondria-related male infertility', Proceedings of the National Academy of Sciences, 103(41), pp. 15148-15153.

Nsonwu-Anyanwu A, Offor S and John I 2018. 'Cigarette Smoke and Oxidative Stress Indices in Male Active Smokers', Reactive Oxygen Species, 5(15), pp. 1-10.

Oyeyipo IP et al., 2011. 'Effects of nicotine on sperm characteristics and fertility profile in adult male rats: A possible role of cessation', Journal of Reproduction and Infertility, 12(3), pp. 201-207.

Papathanasiou G et al., 2014. 'Effects of Smoking on Cardiovascular Function: The Role of Nicotine and Carbon Monoxide Institution of Athens (TEIA), Greece 2. Physical Therapy Department, Technological Educational Institution of Athens (TEIA), Greece 3. Physical Therapy Department, T', Health Science Journal, 8(2), pp. 274-290.

Ramlau-Hansen $\mathrm{CH}$ et al., 2007. 'Is smoking a risk factor for decreased semen quality? A cross-sectional analysis', Human Reproduction, 22(1), pp. 188-196.

Shabanian S et al., 2017. 'The effects of vitamin $C$ on sperm quality parameters in laboratory rats following long-term exposure to cyclophosphamide', Journal of Advanced Pharmaceutical Technology and Research, 8(9), pp. 73-79.

Sutanto EB et al., 2017. 'THE EFFECT OF VITAMIN C AND E COMBINATION ON SPERM QUALITY AND CEMENT 
PENGARUH PEMBERIAN AIR JERUK NIPIS (CITRUS AURANTIFOLIA) TERHADAP KONSENTRASI DAN MOTILITAS SPERMATOZOA MENCIT (MUS MUSCULUS) SETELAH TERPAPAR ASAP ROKOK

8-OHdG LEVEL OF SMOKE EXPOSED RATS', World Nutrition Journal, 1(1), pp. 28-33.

Suthutvoravut S and Kamyarat O 2016. 'Spermicidal effects of lemon juice and juices from other natural products', Agriculture and Natural Resources. Elsevier Ltd, 50(2), pp. 133-138.

Tommola M. et al., 2016. 'The effect of smoking on lung function: A clinical study of adult-onset asthma', European Respiratory Journal, 48(5), pp. 1298-1306. Vijayprasad S, Ghongane BB and Nayak BB 2014. 'Effect of vitamin $C$ on male fertility in rats subjected to forced swimming stress', Journal of Clinical and Diagnostic Research, 8(7), pp. 6-9. 